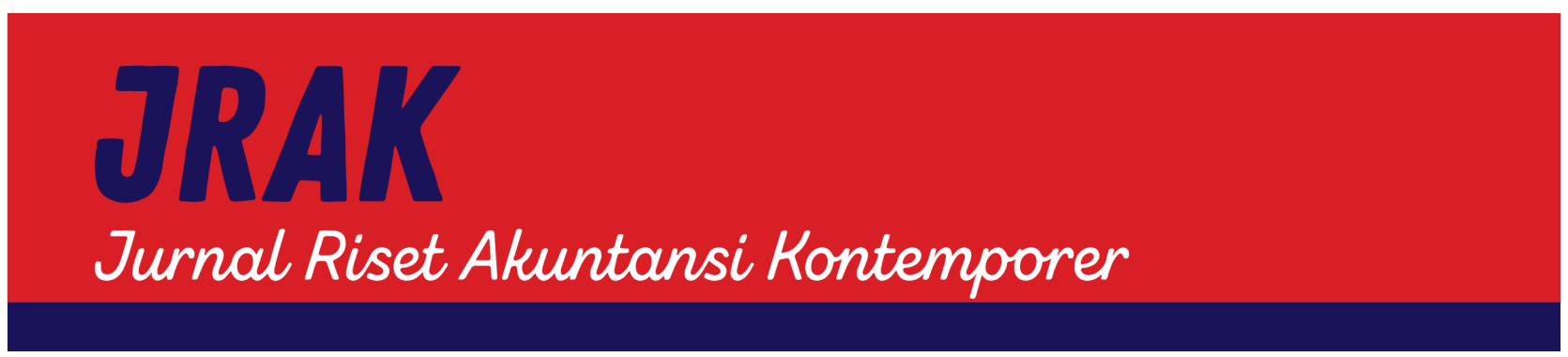

\title{
ANALYSIS OF FINANCIAL STATEMENT IN ASSESSING THE FINANCIAL PERFORMANCE OF LOCAL GOVERNMENT
}

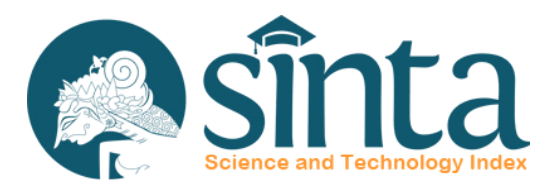

https://journal.unpas.ac.id/index.php/jrak/index

\author{
Helda A. Safitry $₫$, Dwi I. Luhsasi ${ }^{2}$, Carolina L. Permatasari ${ }^{3}$ \\ ${ }^{1,2,3}$ Universitas Kristen Satya Wacana \\ $\bigotimes^{1} 162017020 @$ student.uksw.edu
}

Jl. Diponegoro No.52-60, Kota Salatiga, Jawa Tengah, Indonesia

\section{Article Info}

History of Article

Received: 7/6/2021

Revised: 8/8/2021

Published: 18/10/2021

Jurnal Riset Akuntansi Kontemporer

Volume 13, No. 2, October 2021, Page 65-71

ISSN 2088-5091 (Print)

ISSN 2597-6826 (Online)

Keywords: financial statement; ratio analysis; performance; government; local government

\begin{abstract}
The financial statement can be used to determine company activities, one of them to assess the condition of financial to balance and profit/loss statement. For asses and analyze financial statements are required analysis tools are financial rations. The purpose of this study is to determine the financial performance of the Wiru Village government in 2018-2020. This study uses a qualitative approach with financial analysis tools. The result of this study is Wiru village in 2018- 2020 the self-reliance ratio is very low, effectiveness ratio is very effective, in 2018 the efficiency ratio is not efficient and in 2019-2020 is not efficient, the dependency ratio is very high, and the growth ratio in 2018-2019 has decreased, and then in 2019-2020, it has increased.
\end{abstract}

\section{INTRODUCTION}

The aim of financial statements according to Government Regulation Number 71 of 2010 concerning the Government Accounting Standards, namely presenting information about the financial position, budget realization, cash flow, and financial performance of a reporting entity that is beneficial for users in making and evaluating decisions regarding resource allocation. The final result of this accounting activity is financial statements, this financial statement is the main objective of the accounting activities of an organization including the local government. The Regional Government Financial Reports are often referred to as public financial statements. The Public sector financial statements are a process of collecting, processing, and informing on information that is useful for making decisions and assessing organizational performance. The financial statement of the public sector government consists of budget realization reports, change of cost excess budget balance, balance sheets, operational reports, cash flow reports, reports of change in equity, and notes on financial statements. The main objective of this financial report is to provide information that will be used by potential parties and as a basis for decision-making (Pongoh, 2013).

In addition, according to Faisal (2018), financial performance is an analysis conducted to see the extent to which a company has implemented the use of resolutions of financial implementation properly (Faisal et al., 2018). The financial performance of the local government is the ability of a village in managing and utilizing the real local finances in building villages. One method was used to analyze financial statements is ratio analysis. 
The financial ratio analysis is a tool that is most commonly used in analyzing financial statements (Kartikasari and Wahyuati, 2014). Independence ratio is one of the types of ratio analysis that is used to analyze financial statements. The ratio of local financial independence shows the ability of the local government in financing its government activities, development, and service to the public who have paid retribution tax as a source of acceptance needed by the region (Susanto, 2019). Besides the analysis of the independence ratio, there is also the analysis of effectiveness ratios, efficiency ratios, dependency ratios, and growth ratios.

Based on data obtained from the Financial Report of the Village of Wiru, here is the number of original revenue (Table 1).

Tabel 1. Original Revenue

\begin{tabular}{ccc}
\hline No & Year & Original Local Government Revenue \\
\hline 1. & 2018 & Rp. 89.264.521 \\
2. & 2019 & Rp.16.958.586 \\
3. & 2020 & Rp.6.800.000 \\
\hline
\end{tabular}

In addition, it is also based on financial statements and calculated using the analysis of independence ratio, then the following is the result of the independence ratio of the Wiru Village Government 2018-2020 (Table 2).

Tabel 2. Independence Ratio

\begin{tabular}{ccc}
\hline No & Year & Independence Ratio \\
\hline 1. & 2018 & $6,21 \%$ \\
2. & 2019 & $0,90 \%$ \\
3. & 2020 & $0,34 \%$ \\
\hline
\end{tabular}

Table 2 shows that the independence ratio of the village of Wiru from 2018 - 2020 has decreased. It is necessary to assess the financial performance of the Wiru Village Government in managing financial statements. Therefore the purpose of this study is to find out the financial performance of the Wiru Village Government in 2018 - 2020.

\section{METHOD}

This study uses qualitative methods, this is used so that research can answer the problems and understand the social situation in more depth. The location of this study took place in the village of Kecamatan Wiru Bringin Kabupaten Semarang in 2018 - 2020. This place was chosen because the original local revenue of the village from 2018 - 2020 has a decline, in addition, based on the calculation from the analysis of the ratio of the independence statement from 2018 - 2020 also has decreased.

This study uses secondary data sources, namely document study methods. This study was obtained from the Financial Report of the Wiru Village Government in 2018 - 2020, this is because in 2018 - 2020 the Local Government Revenue (PAD) has decreased and the independence ratio also decreases. In addition, this study also uses primary data sources obtained by conducting direct interviews with the secretary of the Village of Wiru Kecamatan Bringin, Kabupaten Semarang. The techniques of data collection in this study are observations, interviews, and documentation. The technique of data analysis in this study used the analysis of Financial Ratio tools (Table 3).

Tabel 3. Financial Ratio

\begin{tabular}{|c|c|}
\hline Ratio Types & Formula \\
\hline \multirow[t]{2}{*}{ Independence ratio } & PAD \\
\hline & Support Centre $\times 100 \%$ \\
\hline \multirow[t]{2}{*}{ Effectiveness ratio } & Acceptance Realification PAD \\
\hline & Acceptance Budget PAD \\
\hline \multirow[t]{2}{*}{ Efficiency ratio } & Realization of Local Government Budget \\
\hline & Realization of Local Government Revenue $\quad \times 100 \%$ \\
\hline \multirow[t]{2}{*}{ Dependency ratio } & Transfer revenue \\
\hline & Total Local Government revenue \\
\hline \multirow[t]{2}{*}{ Growth ratio } & PAD t1-PAD t0 \\
\hline & PAD t0 \\
\hline
\end{tabular}


This research is almost the same as the research conducted by this study that uses triangulation techniques, it is expected that this study can provide relevant data. This study uses Miles and Huberman models in the book Sugiyono (2015) as a process of analysis of the data used. The stages are carried out by collecting data, data reduction, data presentation, and conclusions.

\section{RESULT}

Based on the calculation of financial analysis of the independence ratio,effectiveness ratio, efficiency ratio, dependency ratio, and growth ratio that has been obtained, it can be concluded in the Table below.

Tabel 4. Independence Ratio

\begin{tabular}{cccc}
\hline No & Year & Independence Ratio & Criteria \\
\hline 1. & 2018 & $6,21 \%$ & Instructive relationship pattern \\
2. & 2019 & $0,90 \%$ & Instructive relationship pattern \\
3. & 2020 & $0,34 \%$ & Instructive relationship pattern \\
\hline
\end{tabular}

Tabel 5. Effectiveness Ratio

\begin{tabular}{cccc}
\hline No & Year & Effectiveness Ratio & Criteria \\
\hline 1. & 2018 & $108,31 \%$ & Criteria are very effective \\
2. & 2019 & $51,60 \%$ & Criteria are very effective \\
3. & 2020 & $100 \%$ & Criteria are very effective \\
\hline
\end{tabular}

Tabel 6. Efficiency Ratio

\begin{tabular}{cccl}
\hline No & Year & Efficiency Ratio & Criteria \\
\hline 1. & 2018 & $100,67 \%$ & Inefficient criteria \\
2. & 2019 & $96,40 \%$ & Inefficient criteria \\
3. & 2020 & $97,23 \%$ & Inefficient criteria \\
\hline
\end{tabular}

Tabel 7. Dependency Ratio

\begin{tabular}{cccc}
\hline No & Year & Dependency Ratio & Criteria \\
\hline 1. & 2018 & $94,15 \%$ & Very high criteria \\
2. & 2019 & $98,93 \%$ & Very high criteria \\
3. & 2020 & $99,49 \%$ & Very high criteria \\
\hline
\end{tabular}

Tabel 8. Growth Ratio

\begin{tabular}{ccc}
\hline No & Year & Growth Ratio \\
\hline 1. & 2018 & $-56,24 \%$ \\
2. & 2019 & $-81,00 \%$ \\
3. & 2020 & $-59,90 \%$ \\
\hline
\end{tabular}

\section{DISCUSSION}

Table 4 shows that in 2018, the ratio of the independence of the village of Wiru was obtained at $6.21 \%$, which means that the pattern is instructive relations. Additionally, in 2019 of the ratio of the Independence of the Village of Wiru was obtained at $0.90 \%$ because of its pattern. In 2020, the ratio of the independence of the Village of Wiru is obtained at $0.34 \%$ because of the same pattern. Be based on this, it can be concluded that during 2018 - 2020 the ratio of independence in the Village of Wiru is very low. This means showing that the Village of Wiru is still cannot be named by an independent village because the independence ratio of 2018 - 2020 is still subordinated.

Based on this, it shows that from 2018 - 2020 the independence ratio of the village every year has decreased. In addition. the financial statements and results of interviews conducted, have decreased the ratio of independence due to the Local Government Revenue (PAD). This is also due to the previous year in 2018, the Local Government Revenue (PAD) reached Rp. 89,264,521 consisting of the results of village assets reached 
Rp. 86,400,000 and other locals revenue of Rp.2,864,521. Whereas in 2019 Local Government Revenue (PAD) was Rp. 16,958,586 consisting of village business results of Rp. 8,751,100 and others its revenue Rp. 8,209,486, and in 2020 the Local Government Revenue (PAD) of Rp. 6,800,000 which only consists of local's business results. This shows that the Local Government Revenue from 2018 - 2020 had a decrease even a drastic decline since 2019. The decline was caused by the finance of BUMDES Amanah in Kecamatan Bringin. BUMDES Amanah has a decline due to the lack of ability of the community to borrow a little, especially during pandemic times. If the income of BUMDES Amanah in Kecamatan Bringin has declined, then the Local Government Revenue (PAD) of the Village of Wiru will have experienced a decline. Moreover, the Local Government Revenue (PAD) from local cash for 'Tanah Bengkok' managed by BUMDES has a crop decline. There is also a Local Government Revenue from BUMDES Sengkuyung, but still in process, so it's not optimal. This is what causes the Local Government Revenue (PAD) to decline.

In addition to the Local Government Revenue (PAD) which caused the independence ratio to decline, there was also an increase in transfer revenue from the central government causing the independence ratio to decline in 2018 - 2020. In 2018, transfer revenue from the central government was Rp. 1,436,569,0005, in 2019 transfer revenue of Rp. 1,877,253,000 and in 2020 transfer revenue of Rp. 2,014,344,891. This shows that the transfer revenue every year has increased, this increase occurred because it was related to Law Number 6 of 2014 that local funds were $40 \%$ of the national budget. If the national income increases, the local funds will also increase. Furthermore, there is a village status, if the village status develops, it will be more compared to the status of the developed villages. The calculation of village status is counted by the State Treasury Offices (KPPN), categorized as the developed village. Due to the status of the Village of Wiru as a developed village, then its transfer revenue has increased, especially the Local Government Income (PAD) in 2018 - 2020 decreased in pandemic times. As a result, it caused transfer revenue to increase by 2018 - 2020.

The results have similarities with research conducted by (Ramadhani et al., 2020) which indicates that the village of Bulak also cannot be said as an independent village because the independence ratio of 2015 - 2017 has very low criteria. In addition, this theory was found in research conducted by Sindi (2019) which showed that the Village of Landungsari also had a ratio of independence during 2016 - 2017 with the criteria for instructive or low relations. This research is due to the transfer revenue from the central government that is greater than the Local Government Revenue (PAD) therefore, the research conducted by Tanan and Duri (2018) also shows that the independence ratio of the Jayapura Municipal Government in 2011 - 2017 is relatively low. There is research conducted by Kaunang and Naukoko (2016) showed the similarities that the independence ratio of Manado City in 2010 - 2014 has low criteria.

Based on table 5 above, shows that the effectiveness ratio in 2018 was $108.31 \%$ with very effective criteria, in 2019 by $51.60 \%$ with very effective criteria, and in 2020 by $100 \%$ with very effective criteria. Supporting all of this, it can be concluded that the effectiveness ratio of the Village of Wiru in 2018 - 2020 is very effective. This means showing that the Government of Wiru village uses the Local Government Revenue (PAD) according to its target in allocating the budget very well.

Based on the financial statements and results of interviews that have been carried out by the effectiveness ratio in 2018 is quite high due to the realization of the receipt of PAD greater than Rp. 89,264,521 compared to the revenue budget of Rp. 86,400,000. Whereas in 2019 the effectiveness ratio has decreased due to the realization of The receipt of PAD and the acceptance budget are the same as Rp. 16,958,586. Additionally, in 2020 the effectiveness ratio has increased again due to the realization of the receipt of PAD and the acceptance budget at the same amount of Rp. 6,800,000. This shows that the realization of PAD acceptance and the acceptance budget PAD every year is uncertain and even cannot be predicted. The realization of PAD acceptance and the acceptance budget in 2018 - 2020 is uncertain because, when making a budget, it must make an estimated number safe. This secure estimation rate is expected if there are raw materials that have increased, it does not exceed the budget or any less. For the realization of receiving PAD, it is not always by the acceptance budget sometimes there is a misunderstanding. Moreover, if there is a change then in September, there will be a change in the budget so that it minimizes errors in the change budget. Sometimes there is a discourse from the central government such as the provincial government will assist with great value but in the realization of the provincial government. This is what causes the realization of receiving PAD is not following the revenue budget.

The results of this study occur because the village can use the Local Government Value (PAD) following its target, as well as research conducted by (Elim et al.,2014) which shows that the Surakarta Municipal Government has succeeded in managing Local Government revenue (PAD) effectively in 2010 - 2011. This research is also the same as research conducted by (Sari and Indriani, 2018) which shows that the ratio of village effectiveness in Kecamatan Ingin Jaya in 2016 is very effective. In addition, the government of Kabupaten Rokan Hulu in 2009 - 2012 also uses PAD according to its target, this can be seen from the research conducted by (Nurhayati, 2015 ) in which indicates that the effectiveness ratio is very effective. There are research residents conducted 
by (Kartika et al., 2016) in Kabupaten Sukabumi in 2009 - 2013 has a very effective effectiveness ratio. Table 6 above shows that the efficiency ratio in 2018 is $100.67 \%$ with inefficient criteria, in $201996.40 \%$ with less efficient criteria, and in 2020 with $97.23 \%$ with less efficient criteria. Based on this, it can be concluded that in 2018 the efficiency ratio of Wiru village is not effective while in 2019 - 2020 the efficiency ratio shows less efficient criteria. This means that in 2018 the financial performance of the Wiru Village Government is inefficient. Moreover, in 2019 - 2020 the performance of the village of Wiru is less efficient in achieving expenses.

Based on the financial statements and results of interviews conducted by the 2018 efficiency ratio which has inefficient in criteria, caused due to the realization of village spending greater than Rp. 1,525,833,521 compared to the realization of village revenue of Rp. 1,535,833,521. Whereas in 2019 the efficiency ratio decreased to less efficient criteria due to the realization of the smaller village who spent of Rp. 1,829,306,505 compared to village revenue realization of Rp. 1,897,573,702 and in 2020, the efficiency ratio has increased by less efficient criteria due to the realization of village spending smaller by Rp. 1,968,646,973 compared to the realization of village revenue of Rp. 2,024,689,707. This shows that sometimes the realization of village revenue cannot cover the village spending realization. in 2018 it cannot cover the realization of village spending due to the realization of its revenue that not following the allocated budget that has been spent. In addition, sometimes there are unforeseen expenses and some shopping realizations that do not match the budget or even exceed. For example, if the raw material has increased, the realization of village spending will also increase. Therefore, the step will be taken by taking the remaining more calculation of the previous year or SiLPA budget to cover the realization of village spending in 2018 so that it does not experience a deficit. This is what causes the realization of village revenue and the realization of village spending is less effective, even ineffective. The research results are almost the same as the research conducted by (Azizi, 2018) which shows that the efficiency ratio of $2015-2018$ is less efficient at six villages in Kabupaten Mungkid, this can happen due to waste. In addition, this study is also the same as what is done by (Lestari et al., 2020) which shows that the efficiency ratio of Bejalen village has less efficient criteria, this is caused by the unforeseen expense. The study also has similarities with research conducted by (Fathah, 2017) in the Gunung Kidul government in 2010 - 2014 shows that the efficiency ratio is relatively inefficient. The research was conducted by (Trianto, 2016) Palembang City in 2003 - 2013 was less efficient and inefficient.

Table 7 above shows that the dependency ratio in 2018 is $94.15 \%$ with very high criteria, in 2019 the dependency ratio of $98.93 \%$ with very high criteria, and 2020 dependency ratio of $99.49 \%$ with very high criteria. Supporting all of this, it can be concluded that the ratio of the Dependency of Wiru Village in 2018 - 2020 has very high criteria. As a result, it shows that the dependence of Wiru Village in $2018-2020$ on the central government is very high.

Based on the financial statements and results of interviews conducted by the dependency ratio of 2018 2020 have very high criteria because from 2018 - 2020 transfer revenue has always increased, so does its total revenue. While the local revenue of the village from 2018 - 2020 has decreased, there are also other earnings such as bank interest which is uncertain and sometimes none.

In 2018, the transfer revenues of Rp.1,436,569,000, the Local Government Revenue of Rp. 89,264,521. As a result, the total village revenue of Rp.1,525,833,521. Whereas in 2019, the transfer revenue of Rp. 1,877,253,000, the Local Government Revenue of Rp. 8,751,100 and other revenues of Rp. 3,362,116. So, the total village revenue of Rp. 1,897,573,702, In addition, in 2020, the transfer revenue of Rp. 2,014,344,891, the Local Government Revenue (PAD) of Rp. 6,800,000 and other revenues of Rp.3,544,816. So that the total local revenue of Rp.2,024,689,707. Based on this, when transfer revenue is compared with the Local Government Revenue (PAD) and other revenues, this is what causes the dependency ratio to have very high criteria of value.

Based on this, the transfer revenue has increased in 2018 - 2020 related to Law Number 6 of 2014 that village funds in the amount of $40 \%$ from the national budget. If state revenues increase, village funds will also increase. In addition, there is also from the village status, if the village status develops like the Village of Wiru, it will be more than the status of the developed villages. Based on this, then the village of Wiru gets some transfer revenues from the central government. In addition, in pandemic conditions, the transfer revenue has increased. For the Local Government Income (PAD) in 2018 - 2020 decreased due to financial in BUMdes Amanah in Kecamatan Bringin to decline. This decline is due to the ability of the people to borrow a little, especially during pandemic times. In addition, the Local Government Revenue (PAD) from the village treasury managed by BUMdes such as cropland has decreased. There is another revenue such as bank interest, and this interest is fluctuating. So that it depends on the funds and is uncertain every year, sometimes it doesn't often happen in 2018. This makes the transfer revenue becomes greater than the Local Government Revenue (PAD), causing a massive value dependency ratio.

The results of this study are the same as research conducted by (Mokodampit et al., 2019) which shows that the dependency ratio of the city of Kotamobagu to the central government is still very high. The dependency 
ratio is very high because the transfer of revenue from the central government has increased. The dependency ratio of Manado city is also very high due to the aid of transfer revenue from the central government has increased, this can be seen from the research conducted by (Elim et al.,2014). This research is also the same as what is conducted by (Rohman, 2020) which also has a ratio of dependence on very high criteria. In addition, the research was carried out by the research conducted by Kamilaus et al., Which shows that Belu Regency has a very high dependency ratio. Table 8 above showed that the growth ratio in 2018 was $-56.24 \%, 2019$ of $-81.00 \%$, and 2020 in the amount of $-59.90 \%$. So it can be concluded that the 2018 growth ratio is greater by $-56.24 \%$ compared to 2019 by $-81.00 \%$ and the growth ratio of 2019 is smaller by $-81.00 \%$ compared to 2020 of $-59.90 \%$. This means showing that the Village of Wiru in 2018 - 2019 growth ratio has decreased, while in 2019 - 2020 growth ratio has increased.

Based on the financial statements and results of interviews that have been conducted by the growth ratio of 2018 - 2020 experiencing minus due to the Local Government Revenue (PAD) from 2018 - 2020 each year decreases. If it is reviewed from the Local Government Revenue (PAD) in 2017 in the amount of Rp. 204,000,000, in 2018, amounting to Rp. 89,264,521, in 2019, in the amount of Rp. 16,958,586 and 2020 in the amount of Rp. 6,800,000. This shows that from 2017 - 2020 the Local Government Revenue (PAD) has decreased. The Local Government Revenue (PAD) experienced reducer due to financial in BUMdes Amanah in Kecamatan Bringin. The decline in Revenue of BUMdes Amanah in Kecamatan Bringin was caused to the lack of ability of its people to borrow a little, especially during pandemic times. In addition, the village treasury managed by BUMdes decreased. To increase the Local Government Income (PAD) BUMdes the Village of Wiru has discourse and many business units. However, who runs new business units of village procurement of goods such as BPNT and cropland managed by BUMdes village treasury. It can be allocated a lot to BUMdes, but if there is no development, it will be pointless. This caused the growth ratio of the Village of Wiru in 2018 - 2020 to go up and down even minus.

The results of this study can occur because the growth ratio has decreased rapidly in Jambu Village. In 2016 - 2017 also had a very drastic decline due to the PAD experienced a decline, this could be seen in the research conducted by (Rohman, 2020) which showed that in the Village of Jambu in 2016 - 2017, the growth ratio experienced a decline. The same research was conducted by (Machmud and Kawung, 2014), and the research conducted by (Susanto, 2019) Showed that the results of the growth Ratio had a number that rose down, this occurred because of the PAD which was uncertain every year. The research conducted by (Nurdiwaty and Zaman, 2016) Kediri City in 2010 with the ratio of negative independence. In addition, the research is done by (Hanik and Karyanti, 2014) shows that the growth ratio of Kabupaten Semarang's financial management revenue and asset service are negative.

\section{CONCLUSIONS}

Based on the results of the evaluation research and analysis that has been carried out, it can be concluded that the financial performance of the Wiru Village government in the independence ratio in 2018 - 2020 is very low so it can be said that Wiru Village cannot be said to be an independent village, because the central assistance is greater than PAD, to increase the ratio of independence, Wiru Village needs to increase PAD. The effectiveness ratio in 2018 - 2020 is very effective, so that Wiru Village can be said to use Village Original Income (PAD) in accordance with its target, therefore it needs to be maintained. The efficiency ratio in 2018 is inefficient because it cannot cover the realization of village expenditures because the realization of village income is not in accordance with the budgeted village income budget, while in 2019 - 2020 it is less efficient because the realization of the village is in accordance with the budgeted village income. but is not maximized, so that in order for the efficiency ratio to be efficient it is necessary to save on village spending. The dependency ratio in 2018 - 2020 is very high, this is because the income from the central government is greater than PAD, so that in order for the dependency ratio to decrease, PAD needs to be increased. Meanwhile, the growth ratio in 2018 is greater than in 2019 this is because PAD in 2018 - 2019 has decreased so PAD needs to be increased, while in 2019 it is smaller than in 2020, so PAD needs to be increased every year so that the growth ratio increases every year.

\section{REFERENCES}

Azizi, A. A. and Mulyanto, M. 2018. Analysis of Government Financial Performance In The Village Income and Expenditure Budget (APBDESA) of Six Villages In Mungkid District Budget Year 2015-2018. Journal of Applied Economics in Developing Countries, 4(2), pp.80-88. 
Elim, I., Tinangon, J. and Kalalo, N. 2014. Pengukuran Kinerja Keuangan pada Pemerintah Kota Manado, Jurnal Riset Ekonomi, Manajemen, Bisnis dan Akuntansi, 2(1), pp. 606-616.

Faisal, A., Samben, R. and Pattisahusiwa, S. 2018. Analisis Kinerja Keuangan, 14(1), p. 6. doi: 10.29264/ jkin.v14i1.2444.

Fathah, R. N. 2017. Analisis Rasio Keuangan untuk Penilaian Kinerja pada Pemerintah Daerah Kabupaten Gunung Kidul, Ebbank, 8(1), pp. 33-48. Available at: http://ebbank.stiebbank.ac.id/index.php/EBBANK/ article/view/109.

Hanik, F. U. and Karyanti, T. D. 2014. Analisis Rasio Keuangan Daerah Sebagai Penilaian Kinerja. Jurnal Akuntansi Bisnis dan Perbankan Indonesia, 22(2), pp. 143-156.

Kartika, D., Setiawan, A.B. and Kusuma, I.C., 2016. Analisis Rasio Kemandirian, Rasio Efektivitas PAD, dan Rasio Efisiensi PAD pada Laporan Realisasi Anggaran Pendapatan dan Belanja Daerah (APBD) Kabupaten Sukabumi. Jurnal Sosial Humaniora, 7(2), pp.143-151.

Kartikasari, M. and Wahyuati, A. 2014. Penilaian Kinerja Keuangan Menggunakan Analisis Rasio pada Bank Mandiri di BEI. Jurnal Ilmu \& Riset Manajemen, 3(11).

Kaunang, C. E. and Naukoko, A. T. 2016. Analisis Kinerja Pengelolaan Keuangan Daerah dan Tingkat Kemandirian Daerah di Era Otonomi Daerah: Studi Pada Kota Manado (Tahun 2010-2014). Jurnal Berkala Ilmiah Efisiensi, 16(2), pp. 355-365.

Lestari, D.D.A., Pertiwi, I.B., Muchlisun, M., Kabib, N. and Anwar, S., 2020. Analisis Kinerja Keuangan Pemerintah Desa Bejalen Kecamatan Ambarawa, Kabupaten Semarang Tahun 2017-2018. Jurnal Ekonomi, Sosial \& Humaniora, 1(09), pp.19-29.

Machmud, M. and Kawung. 2014. Analisis Kinerja Keuangan Daerah di Provinsi Sulawesi Utara Tahun 2007-2012. Jurnal Berkala Ilmiah Efisiensi, 14(2), pp. 1-13.

Mokodampit, Pagemanan and Elim Inggriani. 2019. Analisis Kinerja Keuangan Pemerintah Daerah Kota Kotamubagu. Jurnal EMBA: Jurnal Riset Ekonomi, Manajemen, Bisnis dan Akuntansi 44(12): 2-8

Nurdiwaty, D. and Zaman, B. 2016. Analisis Rasio Keuangan Daerah untuk Menilai Kenerja Keuangan Daerah di Kota Kediri. Journal of Innovation in Business \& Economics, 7(1), pp. 31-40. Available at: https://ejournal.umm.ac.id/index.php/jibe/article/view/jekobisnis.v7i1.3382/pdf.

Nurhayati. 2015. Analisis Rasio Keuangan Untuk Mengukur Kinerja Pemerintah Daerah Kabupaten Rokan Hulu. Jurnal Ilmiah Cano Ekonomos, 4(33), pp. 55-66.

Pongoh, M. 2013. Analisis Laporan Keuangan Untuk Menilai Kinerja Keuangan Pt. Bumi Resources Tbk. Jurnal Riset Ekonomi, Manajemen, Bisnis dan Akuntansi, 1(3), pp. 669-679. doi: 10.35794/emba. v1i3.2135.

Ramadhani, D. A. S., Hisamuddin, N. and Shulthoni, M. 2020. Analisis Rasio Keuangan Untuk Menilai Kinerja Apbdesa (Studi Kasus Desa Bulak Kecamatan Bendo Kabupaten Magetan). Jurnal Akuntansi Universitas Jember, 17(1), p. 1. doi: 10.19184/jauj.v17i1.10687.

Rohman, F. 2020. Analisis Kinerja Keuangan Pemerintah Desa Di Kabupaten Jepara (Studi Kasus Pemerintah Desa Jambu. Jurnal Akuntansi dan Perpajakan, 6(1), pp. 62-75. doi: 10.26905/ap.v6i1.4103.

Sari, R. and Indriani, M. 2018. Analisis Kinerja Pemerintah Desa Dengan Pendekatan Kuantitatif dan Kualitatif (Studi Pada Desa di Kecamatan Ingin Jaya Kabupaten Aceh Besar) Dana Desa Provinsi Aceh Tahun 2016. 3(4), Pp. 688-702.

Sindi, M., 2019. Analisis Kinerja Keuangan Desa Menggunakan Rasio Kemandirian, Rasio Efektifitas, Rasio Efisiensi dan Rasio Pertumbuhan di Desa Landungsari Kecamatan Dau, Kabupaten Malang. Jurnal Agregat, 4(1).

Sugiyono. 2015. Metode Penelitian Kuantitatif, Kualitatif dan Kombonasi (Mixed Methods). Bandung: Alfabeta.

Susanto, H. 2019. Analisis Rasio Keuangan Untuk Mengukur Kinerja Keuangan Pemerintah Daerah Kota Mataram. Distribusi - Journal of Management and Business, 7(1), pp. 81-92. doi: 10.29303/distribusi. v7i1.67.

Tanan, C. I. and Duri, J. A. 2018. Analisis Rasio Untuk Pengukuran Kinerja Keuangan dan Evaluasi Kinerja Keuangan Pemerintah (Studi Kasus Pemerintah Kota Jayapura). Future: Jurnal Manajemen dan Akuntansi, 6(September), pp. 91-101. Available at: https://www.neliti.com/publications/276917/analisisrasio-untuk-pengukuran-kinerja-keuangan-dan-evaluasi-kinerja-keuangan-p.

Trianto, A. 2016. Analisis Efektivitas dan Efisiensi Pengelolaan Keuangan Daerah di Kota Palembang. Akuisisi: Jurnal Akuntansi, 12(1), pp. 65-77. doi: 10.24127/akuisisi.v12i1.92. 